\title{
PERFORMANCE OF MALE AND FEMALE-LED FIRMS
}

\author{
Barbara Liberda*
}

\begin{abstract}
Background. Female-led firms constitute the minority of firms and often perform worse than male-headed firms which leads to losses of female potential and in consequence losses of social welfare. Research on business performance in gender dimension is of importance for policy.
\end{abstract}

Research aims. The goal of this paper is to investigate the relationship between gender of the chief executive officer (CEO) and the performance of firms, based on a survey for Polish innovative firms. We verify the hypothesis of similar performance of innovative firms led by female and male managers.

Methodology. The study is based on data for 265 firms that invested in innovation with a public innovation grant in one industrial region in Poland. Two years after the end of investment, a detailed survey on the firms' performance was conducted in 70 firms representative for the whole sample of 265 firms.

Key findings. The findings indicate that gender of chief executive officers (CEOs) does not differentiate the economic performance of firms. Firms led by male and female CEOs reported a similar increase of employment and returns two years after the investment in innovation. The paper concludes that male and female managers are equally efficient when they do business in similar business conditions with equal access to resources.

Keywords: firm, investment, performance, CEOs, female, male.

This research was supported from the INNOGEND project funded from EEA and Norway Grants in the Polish-Norwegian Research Program operated by the National Centre for Research and Development.

* University of Warsaw. E-mail: barbara.liberda@uw.edu.pl 


\section{INTRODUCTION AND BACKGROUND}

Female-led firms constitute the minority of firms (about one third) and often perform worse than male-headed firms. The underrepresentation and underperformance of firms headed by women lead to losses of female potential and welfare of the whole society (Hsieh et al., 2013). As there is generally a lack of firm-level panel data for male and female businesses, the research on the performance of firms considering also the managers' gender is of great interests to other researchers and for policy related purposes.

Previous research documented the underrepresentation of women in the executives of firms, e.g. Gottschalk and Niefert (2013) and Gagliarducci and Paserman (2015) for Germany, Boyer and Blazy (2014) for France, Shrader et al. (1997) for the USA, Dodd (2012) for the United Kingdom, Boll et al. (2014) in the Baltic Sea region countries, and Skorupinska and Torrent Sellens (2014) for Poland and Germany. Bertrand (2009) revealed the reasons for the underrepresentation of women among executives of top corporations: insufficient formal management training (MBA) of women; biased beliefs of shareholders about the ability of female chief executive officers (CEOs); discrimination against women in corporate and financial sectors and the career-family trade-off that is more binding for women than for men.

Many studies explain the underperformance of women-led firms as compared to firms headed by men, e.g. Gottschalk and Niefert (2013), Gagliarducci and Paserman (2015), Boyer and Blazy (2014), Estrin and Mickiewicz (2011), Verheul et al. (2006), Alsos et al. (2006), and Coleman (2007). Different performance indicators are used (sales, employment and returns) to analyse whether gender differences in education, experience, team size, entrepreneurial motivation, and industry choice explain the differences in the performance of firms. Gottschalk and Niefert (2013) found that female-funded German startup firms perform worse for sales, employment growth, and return on sales. Gagliarducci and Paserman (2015) documented a strong negative correlation between the share of women among top managers and several firm characteristics like: size, investment, wages, employment, and turnover for German establishments.

Boyer and Blazy (2014) found that French enterprises run by men survive longer than those run by women. Based on the Global 
Entrepreneurship Monitor (GEM) data for 29 countries, Verheul et al. (2006) pointed out that female and male entrepreneurial activity rates are affected by the same factors and in the same direction. Estrin and Mickiewicz (2011) indicated that the larger state sector makes women less likely to undertake entrepreneurial activity and the rule of law does not have gender-specific effects on entrepreneurship. Alsos et al., (2006) and Coleman (2007) indicate that the lower levels of financial capital that women founders can secure to develop their businesses are associated with lower business growth compared with male businesses.

Some studies indicate positive effects of higher proportion of women in top management positions for firm performance (Smith et al., 2006; Shrader et al., 1997), or no differences in performance of firms led by women and men (Boll et al., 2014; Kalleberg \& Leicht, 1991). Other studies stress the role of team management, the perceptions of gender equality by chief executive officers (CEOs) and differences in risk aversion of male and female managers for firm performance. Camelo-Ordaz et al. (2005) pointed out that the strategic consensus in the management team is critical for the firm's success. Ragins et al., (1998) show different perceptions of gender equality in management by chief executive officers and other higher level female managers in Fortune 1000 firms. Parrotta and Smith (2013) give evidence of a negative association between a female CEO and the firms' risk attitudes in big Danish companies.

With the growing share of women in the management of firms and in entrepreneurial activity over the last 30 years there has been a rise of the fraction of women in the top percentiles of earnings. However, women still constitute a small proportion of the top of earnings' distribution, also in the finance and insurance industry which reported the highest growth of top earnings in the United States (Guvenen et al., 2014).

In this paper we analyse the performance of Polish innovative firms led by women and men and verify the hypothesis of equal performance of female and male-led firms. The reminder of this paper is structured as follows: in the second section we describe the method of surveying firms and the data used. In the next section we show the main findings of the analysis indicating that innovative firms led by male and female managers do not differ in performance when they operate in similar business environment with equal access to resources, like, for example, innovation subsidy. The paper concludes with the policy implications of our study. 


\section{DATA AND METHOD}

The data used in this research come from a sample of 265 firms benefiting from programs on innovation investment in one industrial region in Poland (Silesia). Basic data were collected from administrative sources of local governments which were responsible for organising calls for funding a part of the firms' innovation investments and for distributing the funds to these firms. Having collected data for 265 firms that benefited from innovation investment grants in the years 2010-2012, we conducted in 2014-2015 a detailed survey among managers in 70 firms that had completed their innovation investment two years before. The detailed survey of 70 firms was representative for the total sample of 265 firms ( $26 \%$ of the total) covering all industries and sub-regions of the studied region (Silesia).

There were two regional programmes granting funds for innovation investment in the region between 2010 and 2012. In one program the funds were granted within a range of $20-60 \%$ of the firm's total innovation investment. There were 140 firms participating in this program (36 firms in the detailed survey) which received on average 0.5 million zlotys (about 125 thousand euros) per firm. In the second program the grant amounted to $40 \%$ of the firm's total innovation investment. There were 125 firms benefiting from this program (34 firms in the detailed survey) which obtained on average 5 million zlotys (about 1.25 million euros) per firm. The main statistics of the total sample are presented in Table 1.

Table 1. Firms participating in innovation investment programs and the chief executive officer's (CEO's) gender

\begin{tabular}{|l|c|c|c|}
\hline $\begin{array}{c}\text { Innovation investment } \\
\text { programs }\end{array}$ & $\begin{array}{c}\text { Innovation grant } \\
\text { zlotys per firm }\end{array}$ & $\begin{array}{c}\text { Number } \\
\text { of firms }\end{array}$ & $\begin{array}{c}\text { Female CEO } \\
\text { in the sample }\end{array}$ \\
\hline 1st programme & 0.52 million & 140 & $20.0 \%$ \\
\hline 2nd programme & 5.3 million & 125 & $10.4 \%$ \\
\hline Total/average & 2.8 million & 265 & $15.5 \%$ \\
\hline
\end{tabular}

Source: survey of firms participating in innovation investment programmes in the Silesian region of Poland between 2010 and 2012. 
However, there is a difference in the share of female chief executive officers (CEOs) between two programs in which the firms participate. In the first programme the share of female CEOs was higher (20\%), but the firms' size as well as the amount of innovation grant was smaller than in the second program. In bigger firms participating in the second investment program the share of female CEOs was smaller (10\%).

In many firms a chief executive officer (CEO) was not directly responsible for getting an innovation grant and then investing it. In about half of the number of firms another manager was responsible for this process. Classification of the managers' gender only by the CEO's gender would not be sufficient for the analysis of managing the innovation investment in firms. Therefore, in the sample of 70 firms that were surveyed in detail, we classified firms by the gender of the firm's CEO or other manager responsible for investment if different from the CEO (Table 2).

Table 2. Managers' gender of innovative firms in one industrial region in Poland

\begin{tabular}{|c|c|c|c|c|}
\hline & \multicolumn{4}{|c|}{ Chief executive officer (CEO) or investment manager } \\
\hline & \multicolumn{2}{|c|}{ Women } & \multicolumn{2}{|c|}{ Men } \\
\hline & \multicolumn{2}{|c|}{$30 \%$ of all firms } & \multicolumn{2}{|c|}{$70 \%$ of all firms } \\
\hline \multirow[t]{2}{*}{$\begin{array}{l}\text { Person responsible } \\
\text { for implementing of } \\
\text { investment }\end{array}$} & $\begin{array}{c}\text { Women } \\
\text { (\% of female-led } \\
\text { firms) }\end{array}$ & $\begin{array}{c}\text { Men } \\
\text { (\% of female-led } \\
\text { firms) }\end{array}$ & $\begin{array}{l}\text { Women } \\
\text { (\% of male-led } \\
\text { firms) }\end{array}$ & $\begin{array}{c}\text { Men } \\
\text { (\% of male-led } \\
\text { firms) }\end{array}$ \\
\hline & 0.33 & 0.67 & 0.27 & 0.73 \\
\hline \multirow[t]{2}{*}{$\begin{array}{l}\text { Person responsible } \\
\text { for accounting } \\
\text { of investment }\end{array}$} & $\begin{array}{c}\text { Women } \\
\text { (\% of female-led } \\
\text { firms) }\end{array}$ & $\begin{array}{c}\text { Men } \\
\text { (\% of female-led } \\
\text { firms) }\end{array}$ & $\begin{array}{l}\text { Women } \\
\text { (\% of male-led } \\
\text { firms) }\end{array}$ & $\begin{array}{c}\text { Men } \\
\text { (\% of male-led } \\
\text { firms) }\end{array}$ \\
\hline & 0.57 & 0.43 & 0.53 & 0.47 \\
\hline
\end{tabular}

Source: survey of 70 firms investing in innovations in one region in Poland, 2014-2015.

Women were CEOs or investment managers in $30 \%$ of firms in the sample of 70 firms which we surveyed in detail. This is twice as much as was the share of female CEOs in the whole sample of 265 firms $(15.5 \%)$. It is due to the fact that in the personalised survey we could precisely indicate the manager who was the leading person in getting the innovation grant and then investing it. 


\section{RESULTS OF ANALYSIS}

The analysis of a detailed survey data in innovative firms show that managing innovation investments does not differ in firms run by female and male CEOs (from here onwards we will use the term CEO for either the CEO or another manager responsible for investment if different from the CEO).

From Table 3 we can infer that similar management rules are visible in male and female CEOs behaviour concerning the structure of the executive boards (Table 3 ).

Table 3. Performance of firms two years after innovation investment: 2014-2015 survey results

\begin{tabular}{|c|c|c|c|c|}
\hline & \multicolumn{4}{|c|}{ Chief executive officer (CEO) or investment manager } \\
\hline & \multicolumn{2}{|c|}{ Women } & \multicolumn{2}{|c|}{ Men } \\
\hline & \multicolumn{2}{|c|}{ (\% of female-led firms) } & \multicolumn{2}{|c|}{ (\% of male-led firms) } \\
\hline \multirow{2}{*}{$\begin{array}{l}\text { Are persons that imple- } \\
\text { mented the investment } \\
\text { project still employed? }\end{array}$} & Yes & No & Yes & No \\
\hline & 0.76 & 0.24 & 0.65 & 0.35 \\
\hline \multirow[t]{2}{*}{$\begin{array}{l}\text { Has employment in- } \\
\text { creased as a result of } \\
\text { investment? }\end{array}$} & Yes & No & Yes & No \\
\hline & 0.86 & 0.14 & 0.78 & 0.22 \\
\hline Increase by $1-3$ persons & 0.48 & & 0.37 & \\
\hline Increase by $4-6$ persons & 0.24 & & 0.18 & \\
\hline Increase by $>6$ persons & 0.1 & & 0.22 & \\
\hline \multirow[t]{2}{*}{$\begin{array}{l}\text { Have returns on sales } \\
\text { increased? }\end{array}$} & Yes & No & Yes & No \\
\hline & 0.95 & 0.05 & 0.96 & 0.04 \\
\hline \multicolumn{5}{|l|}{ Increase of returns $>5 \%$} \\
\hline & 0.62 & & 0.61 & 0.29 \\
\hline \multirow[t]{2}{*}{$\begin{array}{l}\text { Is the firm planning new } \\
\text { innovation investments? }\end{array}$} & Yes & No & Yes & No \\
\hline & 0.76 & 0.24 & 0.71 & 0.29 \\
\hline \multirow[t]{2}{*}{$\begin{array}{l}\text { Will women be members } \\
\text { of the new project team? }\end{array}$} & Yes & No & Yes & No \\
\hline & 0.76 & 0.24 & 0.43 & $0.39 *$ \\
\hline
\end{tabular}

* Missing data sum up to 1.0 .

Source: survey of 70 firms investing in innovations in one region of Poland, 2014-2015. 
In the surveyed sample of firms both male and female CEOs more often choose a male manager to implement the innovation investment. On the other hand, accounting posts were almost equally divided between women and men in both types of firms: with female and male CEOs. These decisions mimic a prevailing behaviour of managers in many firms - women are more often hired as accountants than as acting business managers. Female CEOs also behaved according to such traditional code of conduct.

There are no reasons that managing of firms should differ in male and female CEOs' firms. However, if female and male-led firms are not equally efficient, the gender of the manager is sometimes treated as one of the causes of lower efficiency of women-led firms, besides the firm size, age, industry etc.

The results of our analysis show that the gender of the CEO does not differentiate the performance of innovative firms. There were no significant differences in the economic results of firms with male and female CEOs two years after the innovation investment was done. The increase of employment was on average similar in firms headed by men and women. Female-led firms, being on average smaller than the maleled firms, more often increased employment by 1-3 persons while bigger male-led firms increased employment more often by 6 persons or more.

The increase of returns on investment was the same in firms managed by men and women. Almost all firms increased returns after the innovation investment and more than half of firms increased returns by more than $5 \%$ within two years after the investment. This is quite a good result for the investment in innovation which is characterised by high risk.

However, firms with male and female CEOs exposed different results in stability of employment and outsourcing of services. Stable employment for the project team is guaranteed more often in firms led by women, while in men-led firms implementation of investment was more often outsourced fully or partially. After the investment was made, employees involved in the implementation of the innovation were no longer employed in the investing firm. In firms with a female CEO innovation investment was more often implemented with their own staff, especially in small firms which prevail in this group.

There are obstacles to equal participation of women and men in firm management which are a mixture of objective and subjective (discriminatory) factors. Firms headed by women constitute a minority of firms 
which may cause inertia in the behaviour of active managers rooted in the perception of women as less suitable for the position of CEO or other top management positions. Such behaviour was revealed in this research by active CEOs (both men and women) in recruiting other managers with strong preferences for men and also in the approach to the gender structure of future project teams.

Male managers were much less convinced to include women in future project teams or felt uneasy to answer the question whether women would be members of their future project team (only in this case there were missing answers in the survey). One fourth of female CEOs also expressed a negative attitude towards including women in the future project team. Such behaviour of male and, to a lower extent, female CEOs was similar to their behaviour of recruiting mainly men for project management positions.

Other factors that affect the innovation investment in the whole sample of firms are: the level of development of the sub-region and industry in which the firms operate. The level of development of the sub-region positively affects firms headed by men which were more often situated in the most highly developed central sub-region of the studied region Silesia (Katowice and Gliwice). Operating in manufacturing or in wholesale and retail trade industries positively affects male CEO firms. Female CEO firms are positively affected by doing business in professional, scientific, and technical activities.

\section{DISCUSSION AND CONCLUSIONS}

In this paper we confirmed the hypothesis that men and women are equally efficient in managing firms when the conditions for doing business are equal for them. In the analysed case firms got an equal access to public innovation grant. Based on a sample of firms investing in innovation in one industrial region of Poland we established that there are no significant differences in the economic performance of firms with male and female CEOs two years after the innovation investment was made. Increases of employment and returns were similar in firms of male and female CEOs though firms of men and women differ in stability of employment and outsourcing of services.

There are still barriers to gender equality among managers at a start to business or to new investment due to: low share of female 
CEO firms, inertia in behaviour of the acting managers concerning gender roles and reluctance to include women in the project teams.

The contribution of this paper is twofold: we surveyed the semi-laboratory case of doing business in strictly defined conditions (investing in innovation with a public grant) by firms with male and female managers and we tested the performance of these firms after a twoyear period. However, the results of analysis presented in this paper should be treated with caution due to the limited sample of firms.

The public program of support for innovation is an example of a policy that should be continued possibly with some alterations for covering more social groups. Equal public support to firms led by men and women brings not only direct economic effects but also positive externalities from utilising the potential of women to the benefit of the whole society.

\section{REFERENCES}

Alsos, G.A., Isaksen, E.J., \& Ljunggren, E. (2006). New venture financing and subsequent business growth in men-and women-led businesses. Entrepreneurship Theory and Practice, 30(5), 667-686.

Bertrand, M. (2009). CEOs. Annual Review of Economics, 1(1), 121-150.

Boll, Ch., Bublitz, E., Heller, D., Nitt-Drießelmann, D., Plawgo, B., Tomanek, A., \& Szepelska, A. (2014). Female Entrepreneurship-Evidence from Germany and the Baltic Sea Region and Analysis of Women's Activity in SMEs in Poland, M. Hogeforster (ed.). Baltic Sea Academy, vol. 19, http://www. baltic-sea-academy.eu/publications/\#vol19.

Boyer, T. \& Blazy, R. (2014). Born to be alive? The survival of innovative and non-innovative French micro-start-ups. Small Business Economics, 42(4), 669-683.

Camelo-Ordaz, C., Hernández-Lara, A.B., \& Valle-Cabrera, R. (2005). The relationship between top management teams and innovative capacity in companies. Journal of Management Development, 24(8), 683-705.

Coleman, S. (2007). The role of human and financial capital in the profitability and growth of women-owned small firms. Journal of Small Business Management, 45(3), 303-319.

Dodd, F. (2012), Women leaders in the creative industries a baseline study. International Journal of Gender and Entrepreneurship, 4(2), 153-178. 
Estrin, S. \& Mickiewicz, T. (2011). Institutions and female entrepreneurship. Small Business Economics, 37(4), 397-415.

Gagliarducci, S. \& Paserman, M.D. (2015). The effect of female leadership on establishment and employee outcomes: Evidence from linked employer-employee data. In: S.W. Polachek, K. Tatsiramos, \& K.F. Zimmermann (eds.), Gender Convergence in the Labor Market (pp. 343-375), Research in Labor Economics, vol. 41. Bingley, U.K.: Emerald Group Publishing Limited.

Gottschalk, S. \& Niefert, M. (2013). Gender differences in business success of German start-up firms. International Journal of Entrepreneurship and Small Business, 18(1), 15-46.

Guvenen, F., Kaplan, G., \& Song, J. (2014). The glass ceiling and the paper floor: Gender differences among top earners, 1981-2012 (no. w20560). National Bureau of Economic Research, http://www.nber.org/papers/w20560.

Hsieh, Ch.-T., Hurst, E., Jones, Ch. I., \& Klenow, P.J. (2013). The allocation of talent and U.S. economic growth. Working Paper 18693. National Bureau of Economic Research, http://www.nber.org/papers/w18693.

Kalleberg, A.L. \& Leicht, K.T. (1991). Gender and organizational performance: Determinants of small business survival and success. Academy of Management Journal, 34(1), 136-161.

Parrotta, P. \& Smith, N. (2013). Female-led firms: Performance and risk attitudes. IZA Discussion Paper no. 7613, http://ftp.iza.org/dp7613.pdf.

Ragins, B.R., Townsend, B., \& Mattis, M. (1998). Gender gap in the executive suite: CEOs and female executives report on breaking the glass ceiling. The Academy of Management Executive, 12(1), 28-42.

Shrader, C.B., Blackburn, V.B., \& Iles, P. (1997). Women in management and firm financial performance: An exploratory study. Journal of Managerial Issues, 9(3), 355-372.

Skorupinska, A. \& Torrent Sellens, J. (2014). Drivers of manufacturing firm's productivity in Germany and Poland: Evidence from survey data. Review of Applied Socio-Economic Research, 7(1), 117-124.

Smith, N., Smith, V., \& Verner, M. (2006). Do women in top management affect firm performance? A panel study of 2,500 Danish firms. International Journal of Productivity and Performance Management, 55(7), 569-593.

Verheul, I., Stel, A.V., \& Thurik, R. (2006). Explaining female and male entrepreneurship at the country level. Entrepreneurship and Regional Development, 18(2), 151-183. 


\title{
WYNIKI FIRM KIEROWANYCH PRZEZ KOBIETY I PRZEZ MĘŻCZYZN
}

\begin{abstract}
Abstrakt
Tło badań. Firmy kierowane przez kobiety stanowią mniejszość ogółu przedsiębiorstw i nierzadko osiagają gorsze wyniki niż firmy zarządzane przez mężczyzn. Jest to przyczyną niewykorzystania potencjału kobiet oraz w konsekwencji utraty części możliwego przyrostu dobrobytu społecznego. Dlatego badania przedsiębiorczości w kontekście płci są niezwykle istotne dla polityki gospodarczej.
\end{abstract}

Cel badań. Celem artykułu jest zbadanie związku między płcią dyrektora zarządzającego a wynikami firmy na podstawie ankiety przeprowadzonej w przedsiębiorstwach inwestujacych w innowacje w Polsce. Weryfikacji poddano hipotezę o podobnych wynikach ekonomicznych firm prowadzonych przez kobiety i przez mężczyzn.

Metodologia. Badanie jest oparte na danych z ankiety dla 265 firm inwestujących w innowacje w jednym z polskich województw (śląskim). Dwa lata po zakończeniu przez firmy inwestycji w innowacje przeprowadzono szczegółowe wywiady w grupie 70 firm stanowiącej reprezentatywną próbę dla wszystkich badanych.

Kluczowe wnioski. Wyniki badania wskazuja, że płeć dyrektora zarządzającego firmą nie różnicuje wyników ekonomicznych firm. Firmy zarządzane przez kobiety i mężczyzn wykazały podobne wzrosty zatrudnienia i przychodów dwa lata po zakończeniu inwestycji w innowacje. Konkluzja ogólna z badania jest następująca: firmy zarządzane przez kobiety i mężczyzn osiągają porównywalne wyniki wówczas, gdy działają w podobnych warunkach rynkowych, z równym dostępem do zasobów.

Słowa kluczowe: firma, inwestycje, efektywność, dyrektor zarządzający, kobieta, mężczyzna. 